\title{
Description of Methicilin-Sensitive Staphylococcus aureus (MSSA) and Methicilin-Resistant Staphylococcus aureus (MRSA) against Fluoroquinolone and Vancomycin Group Antibiotics in Jakarta
}

\author{
Conny Riana Tjampakasari ${ }^{1}$, Nadira Afida Kalisya ${ }^{2}$, T. Mirawati Sudiro ${ }^{1}$ \\ ${ }^{1}$ Department of Microbiology, Faculty of Medicine Universitas Indonesia, Jakarta 10430, Indonesia \\ ${ }^{2}$ General Physician Education Program, Faculty of Medicine Universitas Indonesia, Jakarta 10430, Indonesia \\ *Corresponding author: connyrianat@yahoo.com
}

\section{ABSTRACT}

MRSA is Staphylococcus aureus bacteria that is resistant to methicillin and certain antibiotics. These organisms live as commensal bacteria that are transmitted in communities and health facilities which cause various health problems. Patients who develop antibiotic resistance have a worse clinical condition and many lead to death. The purpose of this study was to compare MSSA and MRSA against fluoroquinolone group and vancomycin antibiotics. Specimens derived from various clinical samples sent to microbiology laboratories FMUI for the period 2018-2019. Gram staining and culture is carried out according to the procedure of each colony that grows on the medium. Followed by identification using the automatic machine Vitek $2 \circledR$. A total 62 isolates, 58 were MSSA and the others were MRSA (6.45\%). MSSA patients are in the age range $1->50$ years, dominant in men while MRSA is in the age range $16-30$ and $>50$ years, dominant in women. The sensitivity of the fluoroquinolone group and vancomycin of antibiotics to MSSA was 100\% whereas for MRSA it was $50 \%$ to fluoroquinolone group and $100 \%$ to vancomycin. Vancomycin can be the antibiotic of choice for the management of infections by MRSA bacteria.

Keywords: MSSA, MRSA, antibiotic sensitivity, fluoroquinolone, vancomycin

\section{INTRODUCTION}

MRSA is the resistance of Staphylococus aureus (S.aureus) bacteria to methicillin certain antibiotics, which are used to treat $S$. aureus infection. These microorganisms live as commensal bacteria that are transmitted in communities and health facilities that cause various cases of bacteremia, endocarditis, soft tissue infections, skin, bone and joint infections. Its incidence increased rapidly in the period between the 1990s and early 2000s [1,2,3].
MRSA has become a worldwide health challenge with incidences varying in each region and highest in the United States, Canada and Japan [4,5].

The emergency and the worldwide spread of MRSA represent some of the most important events in the epidemiology of infectious diseases. Although MRSA was first reported in the 1960s, the presence of 209 whole genome sequencing (WGS) of MRSA isolates shows that MRSA actually existed from the mind-1940s, before the introduction of methicillin. Therefore, 
it was hypothesized that the subsequent introduction of methicillin had an impact on presence of MRSA.

The prevalence of MRSA has global variation from low prevalence in Scandinavia to the highest prevalence in the America and Asia [6]. There are no statistical data on MRSA cases in di Indonesia, but based on Phey's study (2014), MRSA cases increased in 2000 compared to the previous year at RSCM [7].

Currently, antimicrobial resistance occurs in all parts of the world and threatens the effectiveness of antimicrobials. Patients with infections caused by bacterial infections who are resistant to antibiotics have a worse clinical condition and many of them lead to death. However, these patients will require higher health resources than patients infected with bacteria without antibiotic resistance [8].

\section{METHODS}

\section{Specimen collection}

Specimen were collected according to operational standard. The specimens came from various types of specimens variations that were sent to the Laboratory of Microbiology, Faculty of Medicine Universitas Indonesia for the period 2018-2019, such as nose and throat swab, tissue and pus.

\section{Gram stain}

Each specimen was stained with Gram's stain (Becton Dickinson) according to standard procedure [9].

\section{Culture}

Specimens were inoculated on Blood Agar, McConkey Agar and Chocolate Agar (Merck), incubated in incubator (Thermo), $35^{\circ} \mathrm{C}$ for 24 hours [9].

\section{Identification}

Gram staining was carried put on the culture results followed by identification based on colony growth on solid medium using an automatic machine Vitek $2^{\circledR}$ Compact (BioMerieux Inc) with a GP identity card [10].

\section{RESULT AND DISCUSSION}

There were 62 of $S$. aureus isolates consisting of $58(93.45 \%)$ MSSA isolates and 4 $(6.45 \%)$ MRSA isolates. Patients with MSSA were in the age range 1- more than 50 years, predominantly male while MRSA were in the range $16-30$ years and more than 50 years, predominantly female (Table and 2).

Based on many studies on the relationship between gender to MRSA, it is known that the incidence is more common in males. This is related to the level of cleanliness that is worse in men than women and the existence of sexual differences resulting in differences hygiene pattern and motivation to be clean. However, work and sports activities are also one the risk factors that are hypothesized to be contributed [3].

Table 1. Distribution of patients with S. aureus infection by sex and age in 2018

\begin{tabular}{cccc}
\hline Variable & $\begin{array}{c}\text { Frequency } \\
\text { S. aureus }\end{array}$ & MRSA & MSSA \\
\hline Sex & & & \\
Male & 24 & 0 & 24 \\
Woman & 15 & 2 & 13 \\
Unknown & 6 & 0 & 6 \\
\hline Age & & & \\
$<1$ & 0 & 0 & 0 \\
$1-15$ & 5 & 0 & 5 \\
$16-30$ & 6 & 1 & 5 \\
$31-50$ & 9 & 0 & 9 \\
$>50$ & 15 & 1 & 14 \\
Unknown & 10 & 0 & 10 \\
\hline
\end{tabular}


In accordance with the research of Gade et al (2013) who distributed MRSA by age group and found a high incidence in the age range of 31-60 years and 61-90 years. MRSA infections are more common in elderly because the older patients generally have more complications and comorbidities, so that their immunity is lower, it can also cause metabolic disorders and increase susceptibility to bacterial resistance $[4,5]$.

Table 2. Distribution of patients with S. aureus infection by sex and age in 2019

\begin{tabular}{cccc}
\hline Variable & $\begin{array}{c}\text { Frequency } \\
\text { S. aureus }\end{array}$ & MRSA & MSSA \\
\hline Sex & & 1 & 9 \\
Male & 10 & 1 & 5 \\
Woman & 6 & 0 & 1 \\
Unknown & 1 & & \\
\hline Age & & 0 & 0 \\
$<1$ & 0 & 0 & 1 \\
$1-15$ & 1 & 0 & 1 \\
$16-30$ & 1 & 0 & 9 \\
$31-50$ & 9 & 2 & 3 \\
$>50$ & 5 & 0 & 1 \\
Unknown & 1 & & \\
\hline
\end{tabular}

The prevalence of positive MRSA in 2018 was 2 from 45 clinical specimens (4.44\%) while in 2019 there were 2 from 17 clinical specimens $(11.7 \%)$. The results are lower than Erikawati, et al (2016) on clinical isolates for period 2010-2014 at RSUD Dr. Saiful Anwar, Malang, Indonesia. Clinical specimens recorded in this study reached a prevalence of $41.8 \%$ in 2011 and $41.7 \%$ in 2010 [11].

In 2018, the MRSA clinical specimens consisted of a nose and throat swab. Nose swab specimen only reported 1 specimen infected with MRSA, while there were 2 throat swab specimens, one of which was infected with MRSA. In 2019, MRSA clinical specimens consisted of tissue and pus specimens. There were 1 in 4 tissue specimens infected with
MRSA and 1 in 2 pus specimens infected with MRSA (Figure 1 and 2).

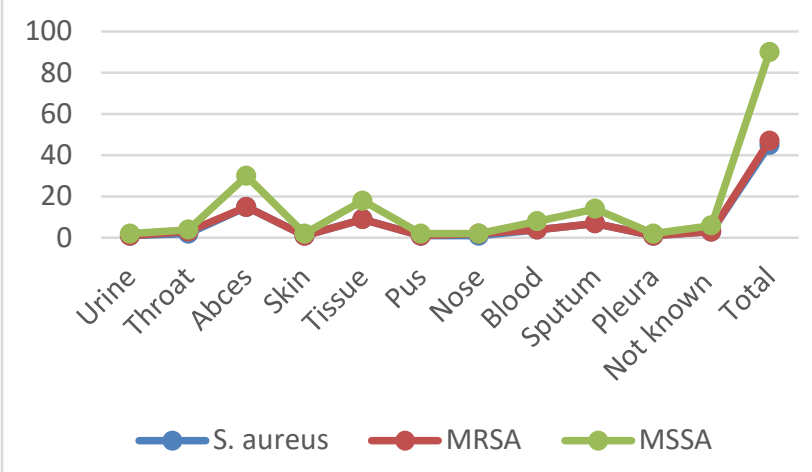

Figure 1. Distribution of specimen in 2018

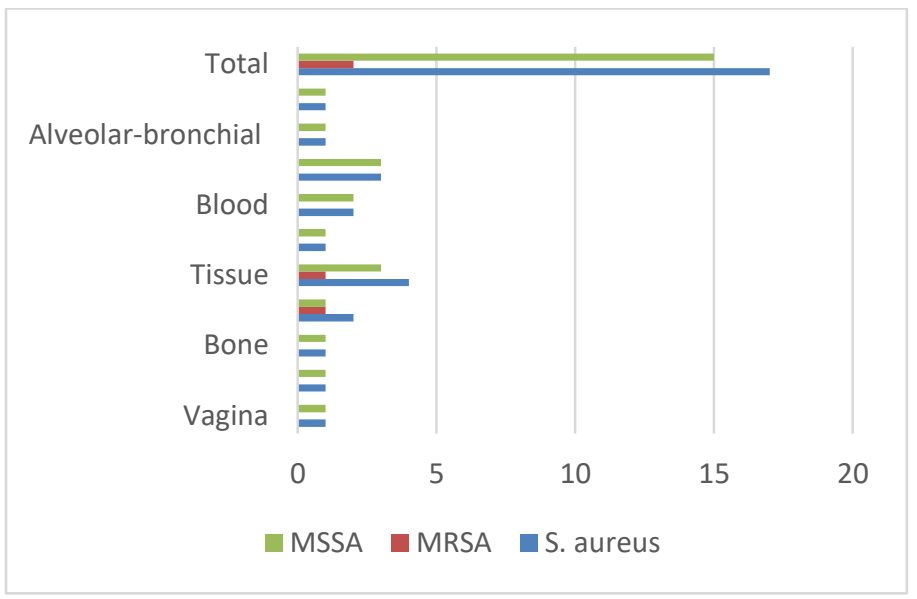

Figure 2. Distribution of specimen in 2019

The pattern of antibiotic resistance of the fluoroquinolone groups and vancomycin to $S$. aureus in 2018-2019 can be seen in Table 3. In 2018 of 45 isolates $S$. aureus, the highest resistance to ciprofloxacin and lefofloxacin was $20.5 \%$ respectively as well as in 2019 of the 17 isolates the the highest resistance to ciprofloxacin and lefofloxacin was $23.5 \%$ respectively. Vancomycin were resistant to $11.4 \%$ in 2018 but none were resistant in 2019. However, the use of vancomycin must really be paid attention to considering there are limitations in its use [12,13]. 
Table 3. Pattern of antibiotics resistance of the fluoroquinolone and vancomycin in $S$. aureus in 2018-2019

\begin{tabular}{lcc}
\hline \multirow{1}{*}{ Antibiotics } & \multicolumn{2}{c}{ Year } \\
\cline { 2 - 3 } & $\begin{array}{c}\mathbf{2 0 1 8} \\
(\mathbf{n = 4 5})\end{array}$ & $\begin{array}{c}\mathbf{2 0 1 9} \\
(\mathbf{n = 1 7})\end{array}$ \\
\hline Fluoroquinolone & & \\
group & & \\
Ciprofloxacin & $20.5 \%$ & $23.5 \%$ \\
Lefofloxacin & $20.5 \%$ & $23.5 \%$ \\
Moxifloxacin & $18.2 \%$ & $1 ., 6 \%$ \\
Vancomysin & $11.4 \%$ & $0 \%$ \\
\hline
\end{tabular}

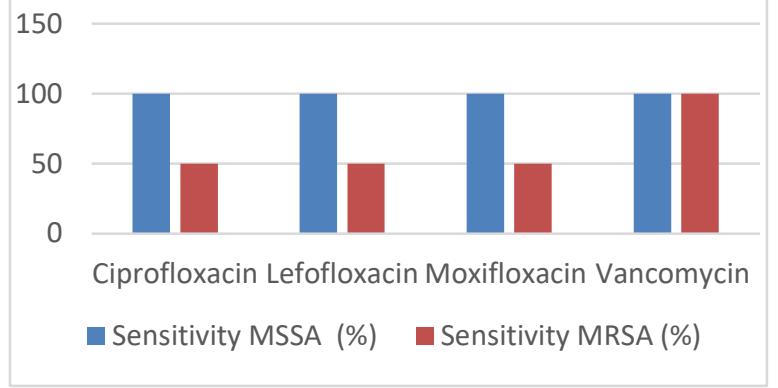

Figure 3. Sensitivity of antibiotics of Fluoroquinolone group (Ciprofloxacin, Lefofloxaciand, Moxifloxacin) and Vancomycin to MSSA and MRSA

The sensitivity of fluoroquinolone and vancomycin to MSSA and MRSA shows that MSSA is $100 \%$ sensitive to both fluoroquinolone and vancomycin. Meanwhile, MRSA was $50 \%$ sensitive to fluoroquinolone groups and $100 \%$ to vancomycin (Figure 3 ).

This is in line with Gade et al (2013) that there are limitations if treatment by fluoroquinolone group for MRSA [5,14]. In fact, ciprofloxacin was declared no longer usable as empirical therapy for MRSA. This is because over past decade, MRSA has developed resistance to fluoroquinolone $[15,16]$.

\section{CONCLUSION}

In MSSA the sensitivity of all antibiotics reached $100 \%$, while in MRSA it was $100 \%$ to vancomycin and $50 \%$ to fluoroquinolone. Vancomycin can be used as the antibiotic of choice for the management of infections by MRSA bacteria.

\section{ACKNOWLEDGMENT}

The authors thank to Clinical Microbiology Laboratory, Department of Microbiology, Faculty of Medicine, Universitas Indonesia for the collection of specimens during the field studies.

\section{REFERENCES}

[1] Green BN, Johnson CD, Egan JT, Rosenthal M, Griffith EA and Evans MW. Methicillin-resistant Staphylococcus aureus: an overview for manual therapists. J Chiropor Med.2012;11(1):64-7

[2] Stefani S, Chung DR, Lindsay JA, Friedrich AW, Kearns AM and Westh H. Methicillin-resistant Staphylococcus aureus (MRSA): global epidemiology and harmonisation of typing methods. Int $\mathbf{J}$ Antimicrob Agents. 2012;39(4):273-82.

[3] Humphreys H, Fitzpatick F and Harvey BJ. Gender differences in rates of carriage and bloodstream infection caused by methicillin-resistant Staphylococus aureus: are they real, do they matter and why?. Clin Infect Dis. 2015;61(11):170814.

[4] Tang J, Hu J, Kang L and Deng Z. The use of vancomycin in the treatment of adult patiens with methicillin-resistant Staphylococcus aureus (MRSA) infection: 
a survey in a tertiary hospital in China. Int J Clin Exp Med. 2015;8(1):19436-41.

[5] Gade ND and Qazi MS. Fluoroquinolone therapy in Staphylococcus aureus infections: where do we stand?. J Lab Physicians. 2013;5(2):109-12.

[6] Lee AS, Lencastre HD, Garau J, Kluytmans J, Malhotra-Kumar $\mathrm{S}$ and Peschel A. Methicillin-resistant Staphylococcus aureus. Nature. 2018;4(18033):1-18.

[7] Phey.L. Gambaran Kuman MethicillinResistant Staphylococcus aureus (MRSA) di Laboratorium Mikrobiologi Departemen Patologi Klinik Rumah Sakit Dr. Cipto Mangunkusumo Periode Januari-Desember 2010. Majalah Kedokteran Sriwijaya. 2014; 46(3):171175

[8] Green BN, Johnson CD, Egan JT, Rosenthal M, Griffith EA, Evans MW. Methicillin-resistant Staphylococcus aureus: an overview for manual therapists. J Chiropor Med. 2012;11(1):64-76.

[9] Cappuccino JG and Sherman N. Microbiology a Laboratory Manual. $10^{\text {th }}$ ed. State University of New York. San Fransisco. Pearson Benjamin Cummings. 2014, p. $29-207$

[10] Biomerieux Vitek 2-User Manual. Biomerieux 2017.

[11] Erikawati D, Santosaningsih D and Santoso S. Tingginya prevalensi MRSA pada isolat klinik periode 2010-2014 di RSUD Dr. Saiful Anwar Malang, Indonesia. Jurnal Kedokteran Brawijaya. 2016;29(2):149-56.

[12] Vandenesh F, Lina G and Henry T. Staphylococcus aureus hemolysins, bicomponent leukocidins, and cytolytic peptides: a redundant arsenal of membrane damaging virulence factors? Front Cell Infect Microbiol. 2012;2(12):110.
[13] Kollef MH. Limitations of vancomycin in the management of resistant staphylococcal infections. Clin Infec Dis. 2007;45(3):191-5.

[14] Masalha M, Borovok I, Schreiber R, Aharonowitz Y, Cohen G. Analysis of transcription of the Staphylococcus aureus aerobic class $1 \mathrm{~b}$ and anaerobic class iii ribonucleotide reductase genes in response to oxygen. J Bacteriol. 2001;183(24):7260-72.

[15] Missiakas DM and Schneewind O. Growth and laboratory maintenance of Staphylococcus aureus. Curr Protoc Microbiol. 2013.9:1-8.

[16] GY. Molecular pathogenesis of Staphylococcus aureus infection. Pediatric Research. 2009;65(5):71-5. 